укрепляет иммунную систему, снимает стресс, помогает чувствовать себя счастливее и увереннее. Улыбающиеся люди физически более здоровы; в их отношении к миру и людям больше позитивного; они привлекательны для окружающих и добиваются в жизни значительно большего («Меньше хмурься, так больше увидишь», «Тот, кто озаряет жизнь других, никогда не останется сам без света»). Добрая, открытая улыбка притягивает к себе людей, поэтому логичен призыв «Улыбайтесь!».

Таким образом, улыбка - наиболее универсальное средство невербального общения, которое может передавать многообразие оттенков чувств и переживаний, возникающих при коммуникации, свидетельствуя о дружелюбии, одобрении, расположении. Это делает её необходимым компонентом и в общении врача и пациента.

$$
* * *
$$

1. Амосов Н.М. Мысли и сердце. - М. : Молодая гвардия, 1969. - 350 с.

2. Мирзоева, В.М. Особенности организационно-педагогической деятельности преподавателя русского как иностранного в медицинском вузе / В.М. Мирзоева, Е.Д. Аксёнова, А.А. Кузнецова, P.A. Ткачёва // Russian journal of education and psychology - 2019. - Том 10, №5. - С. 54-61.

3. Михайлова, Н.Д., Гастрономическая культура России и Индии в зеркале народной мудрости: на примере русских и индийских пословиц и поговорок / Н.Д. Михайлова, Р.А. Ткачёва, Л.Г. Витлинская // Проблемы преподавания филологических дисциплин иностранным учащимся: Сборник материалов VI Международной научно-методической конференции (24-26 января 2020 года). - Воронеж: «Научная книга», 2020. - С. 331-335.

4. Михайлова, Н.Д. Национально-культурная символика в русских и шриланкийских традициях и речевом этикете / Н.Д. Михайлова, Р.А. Ткачёва, С. Сивапалан // Проблемы преподавания филологических дисциплин иностранным учащимся: Материалы 2-й Международной научнометодической конференции (26-27 января 2012 года). - Воронеж: Истоки, 2012. - С. 373-377.

5. Святослав Федоров. Из жизни в жизнь. - М. : Офтальмология, 2013. - 316 с.

\title{
Popova V.B. \\ Article types in saying-proverbial paremias (on the material of the German language)
} Academy of Marketing and Social-Information Technologies - IMSIT (Russia, Krasnodar)

doi 10.18411/gq-31-03-2021-59

idsp sciencerussia-31-03-2021-59

Аннотация
Цель исследования - показать, каким образом в паремиях проявляется
функциональный потенциал типов артикля - определённого, неопределённого,
нулевого. Научная новизна: вариативность особенных признаков определяет тип
используемого артикля, подчёркивается роль метафоры и семантики паремии как
комплекса невариативных типизирующих признаков. В результате доказано, что в
паремиях неопределенный артикль оформляет существительные со значением
поливариативности индивидуальных признаков, определенный артикль - со значением
одновариантности, нулевой - со значением инварианта.
Ключевые слова: паремии, неопределенный, определенный и нулевой типы
артикля; вариативность; инвариант; метафора.

\section{Abstract}

The purpose of the study is to show how the functional potential of article types definite, indefinite, zero types - is manifested in paremias. Scientific novelty: the variability of special features determines the type of the article used, the role of the metaphor and semantics of paremia as a complex of non-variable typified features is emphasized. As a result, it has been proved that in paremias the indefinite article forms nouns with the meaning 
of polyvariability of individual features, the definite article - with the meaning of monovariability, the zero article - with the meaning of an invariant.

Keywords: paremias, indefinite, definite and zero article types; variability; invariant; metaphor.

The use of article types in proverbs and sayings, and more broadly - in phraseological units, "common points", i.e. allusions, aphorisms, allegedly defies classification, the analyzed material is so diverse. Some researchers do not consider it possible to identify patterns in the use of article types in such cases. For example, in Grimm's and Kempter's works it can be found as follows (the following symbols are used: *A - zero article, $+\mathrm{A}-$ definite article; -A - indefinite article; author's translation (V.P.)):

"In such non-phraseological constructions it would be possible or even necessary to apply another article" (not a zero article - V.P.), No. 37 [1, p. 152] or "*A is stably lexicalized in contradiction to the rules used for non-phraseological constructions", No. 37 b, [1, p. 152], or "In certain situations, *A is used with the nouns that are used with $+\mathrm{A}$ or $-\mathrm{A}$ outside these situations (author's italics - V.P.)" No. 23, [1, p. 101].

As a commentary on the quotation, it can be suggested that articles before nouns in proverbs and sayings should not be considered outside the situations described by these language units.

"Paremic units ....act as a connecting link between language (in the traditional sense, as a set of elements constituting speech and discourse) and speech as a level of communicativefunctional realization. Due to their reproducibility and (presumably) they are known to a native speaker, they belong to the language; due to their structural organization and communicative significance, they seem to be like frozen speech formations" [2, p. 5]. Moreover, their meaning is an invariant correlated with a specific speech situation, which is its manifestation, a variant. The meaning expressed by paremia is represented in the semantic sense by the core of general non-variational features packed in a figurative form, the variable features are expressed by the reference situation. Figurativeness is an integral characteristic of phraseological units.

Wir sitzen in einem Bot - All of us are in the same boat. This phraseological unit is most appropriate in the event of a pandemic. Nothing else needs to be explained. The conclusions are implicitly contained in the statement (it can be noted in parentheses that there is no article in this phraseological unit, the pronoun "one" is used; phraseological expressions from various phraseological dictionaries of the German language are used hereinafter).

Phraseological units are characterized by reproducibility, regular recurrence, being well-known and folkloric in nature. This is determined by the fact that "proverbs are a kind of "condensation of thought" (A.A. Potebnya), formed at the most essential, nodal points of the cognitive space of native speakers. Thus, most of them reflect typical cases or situations faced by human beings and, despite their frequent occurrence, have something that continues to provoke people to repeat rash actions" [2, p.10].

"Paremias in their pragmatic aspect teach, educate, warn, advise and in this respect, they act as a culture-forming factor, at least as long as there are precedents that cause their occurrence" [2, p. 11].

It should be added that the actual situation described by the paremia may no longer fully correspond to the realities of modern times, but the vivid image, once created and fixed in the paremia precisely because of its brightness, continues to effectively influence the recipient, causing certain emotions. "Consciousness and emotions cannot be separated. (Although... - V.P.) Non-disjunctiveness of consciousness and emotions is difficult to accept" [3].

Below is the description of the use of article types in paremias.

The definite article. "Die Bekanntschaft mit dem Einzelnen kann schon durch blosen Gebrauch des bestimmten Artikels zum Ausdruck kommen" [4, p. 272] - "The use of the 
definite article is enough to evoke the feeling of the familiar singular" (author's translation V.P.). This quote can be supplemented with an allusion from the Russian language "I can recognize my sweet one by the walk". The definite article gives confidence in the known form, the ratio of parts, the interaction of the characters involved, to recognize its content, to learn the "familiar meaning". The variability of the form is presented as monovariability: the way the recipient imagined it. This helps to easily guess the known meaning. These are often the everyday "slice-of-life" situations:

Der Apfel fällt nicht weit vom Stamm - Like father like son (word-for-word translation: - The apple falls near the trunk); somebody;

für jemand. die Kastanien aus dem Feuer holen - drag chestnuts out of the fire for

Man muss den Stier bei den Hörnern packen - The bull must be taken by the horns;

Da hast du aber die Katze im Sack gekauft - You bought a cat in the sack;

dastehen wie die Kuh vorm neuen Tor - stand like a ram in front of a new gate (wordfor-word translation: stand like a cow in front of a new gate);

um den heißen Brei herumreden - talk in circles (word-for-word translation: talk around hot porridge;

die Kuh vom Eis holen - drag a cow off the ice (rescue a lost cow. It is about a rather difficult task: compare in Russian like a cow on ice).

Attention should be paid to the metaphorical nature of the statements.

The meaning formed by the genre picture is used as a metaphor for the corresponding real situation.

Besides, the images are very bright, specific, they can be well represented. If the saying is about porridge, it seems hot, if it is about an apple, then it has just fallen from the tree and rolled down, the bull is associated with horns, while chestnuts - with the ones from the burning hearth. Even a cat in the sack is perfectly "visible", like the outlines of an uneven bulge, which is likely to move. accepted.

Such pictures inspire the recipient's trust. The meaning of a metaphor is easily

The function of the definite article is formulated by some researchers as ensuring the beauty of the narrative: "aesthetics (definite article) means completeness, poise, readability, harmony, beauty of a phrase or word combination" $[5, \mathrm{p} .6]$.

Also, a factor dictating the choice of the definite article is spatial proximity, including spatial and semantic, paradigmatic juxtaposition - synonyms, antonyms, part of the whole.

Glück im Unglück (1) - A blessing in disguise (word-for-word translation: Happiness in misery);

Jemand hat Sonne im Herzen (2) - Sunshine person (word-for-word translation: a person with a sun in his heart).

In the quoted expressions im Unglück - in misery, im Herzen - in the heart are accordingly marked with the definite article as a location. Moreover, in the first case, there is an opposition of antonyms, evidence of contrast. In the second case, the relationship is part of the whole, heart $\rightarrow$ human body.

The zero article (in words happiness and sun in the examples above) is characteristic of images - broad generalizations that represent a complex compositional whole addressed to abstract concepts. Sun in the expression sun in the heart is a broad generalization, in fact, it is not the sun, but its main characteristics: warmth and light; a person supposedly shines, transferring a positive attitude towards the world and people. Metaphor. Recall that in didactic literature, a lexeme sun is often cited as an example of a noun that defines a unique object and is always used with the definite article. However, this description does not correspond to cases of metaphorical transfer. An abstract vocabulary, an appeal to the world of ideas is often marked with the zero article. Thus, one can distinguish a lexeme ice in the expression die Kuh vom Eis holen - drag a cow off the ice, where ice is a fragment of the ice cover on which the 
cow stands, and ice in a metaphorical generalization in the following expression: Sie ... legt ihre eigene Schauspielkarriere auf Eis [6]. - She gives up on her career.

As is seen, the word ice can even be omitted in translation, "froze the career" cannot be considered as a translation equivalent. The word ice only gives a feeling of immovability, lack of development, and in the German version - cold and stagnation, freezing as an end to life. The focus of attention is not on the object itself - ice, but on its qualities. This involves getting away from the form and shifting to the content, essence, the main characteristic. This is a super-generalization. Metaphor.

The dominant quality in its purest form, taking into account all the variants of its possible embodiment, when the many-sided individual is also taken into account, but not accentuated in any way, is the prerogative of the zero article. There is some quality, the variability of the manifestation of which is not so important.

It means that the accompanying zero article removes the emphasis towards the manifested individual, as in cases with the definite article, or the variational particular, as in cases with the indefinite article. The word appears as a dual unity of the general and the particular, but the domination of typification is obvious. This is an invariant that includes all possible variants.

The indefinite article emphasizes the general, leaving the valence of the particular empty, unfilled. The recipient has the right to fill it in at his own discretion, giving free rein to fantasy:

jmdm. einen Bären aufbinden - word-for-word translation tie to someone a bear on the $b a c k \approx$ give a long song and dance; i.e. tell a lie with restless fantasies;

einen Besen fressen - to eat a broom - cross one's heart and hope to die; i.e. harm oneself deliberately;

aus einer Mücke einen Elefanten machen - word-for-word translation: make an elephant out of a mosquito $\approx$ make something out of nothing, i.e. greatly exaggerate.

Indeed, maybe there is such a fly from which one can make some kind of elephant, maybe there is such a bear that can be tied to someone on the back, maybe there is such a broom that could be eaten, even if this process is unpleasant. The variability of the particular is emphasized.

Thus, "the polyvariability of the particular, demonstrated by the indefinite article, is especially clearly manifested in phraseological units. Many images that are close to the virtual ones are remembered as scenes from the theater of the absurd: the variety of variants indirectly orients the listener to any variant as conditionally acceptable. These images are associated with a stretch of imagination, the most detached from reality and the indefinite article allows accepting them as permissible to some extent" [7, p. 29].

Thus, the functional status of article types does not change depending on the type of the text, in particular the sentence; this status remains the same in paremic expressions. The variability of the particular, manifested in the specified singular, determines the type of the article. Namely (mathematical symbols are used, "A" indicates the singular):

$\mathrm{A} \leq 1$, for the indefinite article, i.e. $\mathrm{A}$ is the singular less the individual, potential polyvariability;

$\mathrm{A}=1$, for the definite article, the individual is manifested in the singular in such variant, monovariability;

$\mathrm{A} \geq 1$, for the zero article, the individual and the essential are taken in all possible completeness, the compositionally complex whole or the integral, an invariant.

$$
* * *
$$

1. Kempter, F. (1989). Kleine deutsche Artikellehre für Ausländer: Regeln u. Übungen. Search RSL Retreived December 21, 2020 from https://search.rsl.ru/ru/record/01000484173.

2. Sidorkov, S.V. (2003). Saying-proverbial paremias as a factor in the structural and semantic organization of discourse (PhD Thesis Abstract). Krasnodar. 
3. Aleksandrov, Yu.I. (2017). Non-disjunctive approach to consciousness and emotion: a culture-specific view. In The Dalai Lama and Russian Scientists. Dialogues about the nature of consciousness. Session 1. Retrieved January 21, 2021, from https://www.youtube.com/watch?v=WaQF264gN5c.

4. Walter, J. (1966). Grammatik der deutschen Sprache. Retrieved March 21, 2021, from https://rusneb.ru/search/?f_field[publisher]=f/publisher/Veb\%20bibliographisches\%20institut.

5. Tchaikovskaya, R.A. (1998). Article in Spanish. Moscow: NVI-TEZAURUS.

6. Alain Delon, persönlich - Docu. (2016). Retrieved December 21, 2020, from: https://yandex.ru/video/search?text=Alain\%20Delon\%2C\%20pers\%C3\%B6nlich\%20-

$\% 20$ Docu\%20(2016)\&path=wizard\&wiz_type=vital.

7. Popova, V.B. (2001). Metalanguage foundations of the functional status of an article (PhD Thesis Abstract). Krasnodar. 